\title{
ELECTRONIC ADMINISTRATION OF VALUE ADDED TAX: LEGAL ASPECT
}

\author{
ЕЛЕКТРОННЕ АДМІНІСТРУВАННЯ ПОДАТКУ \\ НА ДОДАНУ ВАРТІСТЬ: ПРАВОВИЙ АСПЕКТ
}

\section{Andrii Lohvyn ${ }^{1}$}

DOI: https://doi.org/10.30525/978-9934-26-077-3-38

Abstract. The author of the article explores the legal aspect of the system of electronic administration of value added tax, in particular, the legal regulation of some issues of electronic accounts (operations on them). The development of modern information technologies and their wide implementation in the mechanisms of state (power) management contributes to the emergence of new economic and legal relations, including those regarding taxes and fees. The mentioned above applies to the administration of value added tax. At the same time, one of the mandatory structural features of the state is the taxation system because one of the goals of state regulation is the system of taxes and fees administration, within which, on the one hand, the collected taxes should be sufficient to ensure the fulfillment of tasks and to perform the functions facing the state, and on the other hand, the burden of the tax procedure should not be excessive for a taxpayer. In turn, the main legal issues of the tax sphere mainly involve determining and effective ensuring the limits of freedom and necessity in the behavior of tax entities through relevant legal, legislative norms, in the protection of property rights of individual payers and public interests that are implemented in the financial and tax activities of the state. A sufficiently wide attention has been paid to this process since the introduction of the electronic administration of value added tax. Thus, there arises a need for further scientific research into the introduction of electronic administration of value added tax, especially its legal regulation, including the operations with electronic accounts. The article analyzes the current state of regulatory consolidation of the procedure for the operation of electronic accounts, in

${ }^{1} \mathrm{PhD}$ in Law,

ORCID: https://orcid.org/0000-0003-4373-375X 
particular, those related to transactions on their replenishment (receipt of funds) and return of overpaid funds, as well as the impact of such transactions on the registration limit. This made it possible to identify problematic issues of a legal nature, which lead to a violation of balance in relations between a taxpayer and the budget system, to find the ways to solve them and draw scientifically based conclusions on the outlined problems.

\section{1. Ветуп}

Наявність податку на додану вартість в податковій системі будьякої країни європейського простору є обов'язковим для вступу до Європейського союзу. Також, у світовій практиці податок на додану вартість вважається одним 3 найбільш ефективно працюючих податків $з$ фіскальної точку зору. Однією з обов' язкових структурних ознак держави є система оподаткування, бо однією з цілей державного регулювання є така система адміністрування податків і зборів за якої, 3 одного боку, зібраних податків повинно бути достатньо для забезпечення виконання завдань та здійснення функцій, які стоять перед державою, а з іншого - тягар процедури справляння податків не повинен бути надмірним для платника.

Реформування в будь-якій сфері суспільного життя $є$ тим необхідним процесом, що покликаний усувати недоліки функціонування певної системи, іiі інститутів, і насамперед недоліки структурного характеру, які виявляються під час діяльності системи в існуючому форматі. Але покликання реформи не лише у цьому. Реформування - механізм, що дає змогу побудувати більш ефективну, ніж існуюча, систему, навіть і в тому разі, якщо видимі недоліки не критичні. Розвиток сучасних інформаційних технологій та їх широке впровадження в механізми державного (владного) управління сприяє виникненню нових економічних та юридичних відносин, в тому числі в частині справляння податків і зборів. Вказане не оминуло адміністрування податку на додану вартість.

При цьому, головна юридична проблематика податкової сфери полягає переважно у визначенні та ефективному забезпеченні меж свободи й необхідності у поведінці суб'єктів податкових правовідносин через відповідні правові, законодавчі норми, у захисті права власності окремих платників та інтересів суспільства, які реалізуються у фінансово-податковій діяльності держави. 
В свою чергу, сплата податку на додану вартість (далі за текстом ПДВ), поповнення (збільшення реєстраційного ліміту) електронних рахунків, відкритих в системі електронного адміністрування податку на додану вартість (далі за текстом - система електронного адміністрування ПДВ, СЕА ПДВ), відбувається за рахунок власних (обігових коштів) платників податку. При цьому, за певних обставин (наприклад: переплата) вказані кошти за необхідності можуть бути повернені платником податку на його поточний рахунок. У зв'язку з чим, майнова вигода від своєчасного та вірного відображення таких операцій (належне закріплення їх з правової точки зору) на електронному рахунку платника податку є очевидною.

У зв'язку з чим постає необхідність подальших наукових досліджень $з$ питань запровадження електронного адміністрування податку на додану вартість, тим більше правового аспекту вказаного процесу, в тому числі в частині операцій з електронними рахунками (поповнення, повернення) та їх вплив на реєстраційний ліміт.

В статті на основі аналізу чинного законодавства та судової практики визначено проблемні питання правового регулювання роботи з рахунками в системі електронного адміністрування податку на додану вартість (далі за текстом - електронний рахунок) та шляхи їх вирішення. Крім того, зроблено науково обгрунтовані висновки з окресленої проблематики.

\section{2. Електронне адміністрування податку на додану вартість.}

Адміністрування податків і зборів є однією з ознак держави та важливою складовою іiі існування. Термін “адміністрування податків" $\epsilon$ досить популярнішим і загальновживаним у фінансовій та науковій літературі, у публічних виступах політиків, посадовців різного рівня.

Основне завдання системи адміністрування податків полягає у забезпеченні якісного обліку платників податків, повноти та своєчасності надходжень податкових платежів до бюджетної системи згідно 3 вимогами чинного Податкового кодексу. Звідси ефективність адміністрування податків повинна характеризуватися рівнем надходжень податків та зборів до бюджетів різних рівнів та критерієм рентабельності системи адміністрування. Також ефективність адміністрування досягається за рахунок її належного нормативного закріплення та правового підгрунтя відповідних положень. 
Вимоги сучасності та розвиток інформаційних технологій передбачає їх широке впровадження в механізми державного (владного) управління та сприяє виникненню нових економічних та юридичних відносин, в тому числі в частині справляння податків і зборів, зокрема, запровадження електронного адміністрування податків, насамперед податку на додану вартість.

У своїх попередніх публікаціях на основі аналізу норм чинного законодавства ми досліджували становлення (генезис) електронного адміністрування податку на додану вартість. Крім того, обгрунтовувалась необхідність введення наукової та правової категорії «електронне адміністрування податку на додану вартість», визначено його складові (до яких також віднесено електронні рахунки), предмет, суб' ‘кт, об'єкт.

Доречним буде нагадати, що електронне адміністрування податку на додану вартість забезпечує автоматичний облік в розрізі платників податку: суми податку, що містяться у виданих та отриманих податкових накладних та розрахунках коригування, зареєстрованих в Сдиному реєстрі податкових накладних (далі за текстом - СРПН); суми податку, сплачені платниками при ввезенні товару на митну територію України; суми поповнення та залишку коштів на рахунках в системі електронного адміністрування податку на додану вартість; суми податку, на яку платники мають право зареєструвати податкові накладні та розрахунки коригування до податкових накладних в СРПН. Платникам податку автоматично у Державній казначейській службі (далі за текстом - Держказначейство, Казначейство) відкриваються рахунки в системі електронного адміністрування податку на додану вартість, які також забезпечують можливість здійснення розрахунків з бюджетом (шляхом їх поповнення). При цьому сплата податкових зобов'язань 3 податку на додану вартість може здійснюватися і з поточного рахунку платника податку, відкритого у банківській установі.

На даний час на законодавчому рівні не змінились нормативні акти, якими визначається та регулюються порядок електронного адміністрування ПДВ, до яких відносяться Податковий кодекс України (далі за текстом - Податковий кодекс) [1], Постанова Кабінету міністрів України від 29.12.2010 р. № 1246 (далі за текстом - Постанова № 1246) [2], Постанова Кабінету Міністрів України від 16.10.2014 р. № 569 (далі за текстом - Постанова № 569) [3]. 
Правове регулювання механізму електронного адміністрування податку на додану вартість покликано впорядкувати правовідносини, які виникають під час адміністрування (справляння) податку на додану вартість, забезпечити контроль за виконанням своїх обов'язків платниками податків та прав контролюючих органів. Предметом правового регулювання в даному випадку виступають відносини, які виникають під час відкриття та роботи електронних рахунків (їх поповнення), реєстрації податкових накладних/ розрахунків коригування, визначення податкових зобов'язань (звітність) та сплати податку на додану вартість, бюджетного відшкодування. Суб'єктами правовідносин $є$ платники податку на додану вартість, контролюючі органи (на зараз Державна податкова служба України) (далі за текстом - ДПС України, контролюючий орган); органи казначейства (Державна казначейська служба України). Об'єктом правовідносин є не тільки кошти платників, які надходять у вигляді податку на додану вартість до бюджету та поповнення електронних рахунків, а й права і дії щодо електронних рахунків (відкриття, закриття та операцій на них (поповнення грошовими коштами та повернення грошових коштів) та реєстрації податкових накладних (реєстраційний ліміт).

Однією 3 характеристик правосуб'єктності платника податку на додану вартість $є$ їхні права у системі електронного адміністрування ПДВ, які є вихідними засадами їх правового статусу. Саме завдяки правам платників податків у системі електронного адміністрування податку на додану вартість проявляються їх інтереси, діяльність, а також взаємозв'язок з іншими суб'єктами СЕА ПДВ (контролюючі органи в особі Державної податкової служби України та органами Державної казначейської служби України).

\section{3. Електронні рахунки}

Як вже було зазначено електронні рахунки є складовою системи електронного адміністрування ПДВ. Призначені для ведення обліку суми податку на додану вартість (реєстраційний ліміт), на яку платник податку може зареєструвати податкові накладні під час продажу товарів (послуг). Враховують суми ПДВ (показники) за отриманими податковими накладними або коштів, самостійно перерахованих платником (як поповнення для збільшення реєстраційного ліміту). Дореч- 
ним буде звернути увагу, що п. 2001.3 ст. 2001 Податкового кодексу [1] визначено формулу:

$$
\Sigma_{\text {Накл }}=\sum_{\text {НаклОтр }}+\sum_{\text {Митн }}+\sum_{\text {ПопРах }}+\sum_{\text {Овердрафт }}-\sum_{\text {НаклВид }}-\sum_{\text {Відшкод }}-\sum_{\text {Перевищ }},
$$

за якою обчислюється сума ПДВ, на яку платник податку має право зареєструвати податкові накладні та/або розрахунки коригування в ЄРПН. У даній статті ми не будемо детально розглядати кожну складову зазначеної формули, оскільки в нашому випадку, з огляду на тему статті, вони не мають суттєве значення (крім показника $\sum_{\text {Попрах }}$ на якому зупинимось далі).

Також, за допомогою електронного рахунку проводяться розрахунки з бюджетом. Доречним буде звернути увагу на те, що Податковим кодексом не заборонена сплата ПДВ до відповідного бюджету 3 поточного рахунку платника податку, відкритого в установі банку.

Переходячи до питання правового регулювання роботи електронних рахунків слід зазначити, що відповідно до п. 4 Постанови № 569 [3] рахунок у системі електронного адміністрування податку рахунок, відкритий платнику податку в Казначействі, на який перераховуються кошти відповідно до пункту $200^{1} .4$ статті $200^{1}$ Податкового кодексу. Електронний рахунок відкривається платнику податку Казначейством автоматично на безоплатній основі. В свою чергу п. $200^{1} .4$ ст. $200^{1}$ Податкового кодексу [1] передбачено які саме кошти можуть бути зараховані на електронний рахунок платника податку.

При цьому чинним законодавством (ст. 43 Податкового кодексу [1]) визначено, яким чином може бути здійснено повернення надміру сплачених сум грошових зобов'язань, в тому числі з податку на додану вартість. Так, помилково та/або надміру сплачені суми грошового зобов'язання підлягають поверненню платнику відповідно до цієї статті та статті 301 Митного кодексу України, крім випадків наявності у такого платника податкового боргу.

Обов'язковою умовою для здійснення повернення сум грошового зобов'язання та пені є подання платником податків заяви про таке повернення. Платник податків подає заяву про повернення помилково та/або надміру сплачених грошових зобов'язань та пені у довільній формі, в якій зазначає напрям перерахування коштів. 
В такому разі контролюючий орган не пізніше ніж за п'ять робочих днів до закінчення двадцятиденного строку з дня подання платником податків заяви повинен підготувати висновок про повернення належних сум коштів з відповідного бюджету або з єдиного рахунку та подає його для виконання до органу, що здійснює казначейське обслуговування бюджетних коштів. В свою чергу, на підставі отриманого висновку орган, що здійснює казначейське обслуговування бюджетних коштів, протягом п’яти робочих днів здійснює повернення помилково та/або надміру сплачених грошових зобов'язань та пені платникам податків у порядку, встановленому центральним органом виконавчої влади, що забезпечує формування та реалізує державну фінансову політику. При цьому, контролюючий орган несе відповідальність згідно із законом за несвоєчасність передачі органу, що здійснює казначейське обслуговування бюджетних коштів для виконання висновку про повернення відповідних сум коштів з відповідного бюджету.

Разом 3 цим, у разі повернення надміру сплачених податкових зобов'язань 3 податку на додану вартість, зарахованих до бюджету 3 рахунка платника податку в системі електронного адміністрування податку на додану вартість у порядку, визначеному пунктом $200^{1} .5$ статті $200^{1}$ Податкового кодексу, такі кошти підлягають поверненню виключно на рахунок платника в СЕА ПДВ, а у разі його відсутності на момент звернення платника податків із заявою на повернення надміру сплачених податкових зобов'язань 3 податку на додану вартість чи на момент фактичного повернення коштів - шляхом перерахування на поточний рахунок платника податків в установі банку.

Водночас, в даному випадку йдеться про порядок повернення коштів, які перераховані до бюджету, саме 3 електронного рахунку. Однак, і кошти, зараховані до бюджету (як сплата грошових зобов'язань) не з електронного рахунку (наприклад: $з$ поточного рахунку платника податку), також повертаються контролюючим органом в такому ж порядку на електронний рахунок.

Слід звернути увагу, що відповідно до п. $200^{1} .5$ ст. $200^{1}$ Податкового кодексу [1], з електронного рахунку платника податку перераховуються кошти до державного бюджету в сумі податкових зобов'язань 3 податку на додану вартість, що підлягає сплаті за наслідками звітного податкового періоду, та на поточний рахунок платника податку за 
його заявою, яка подається до контролюючого органу у складі податкової звітності з податку на додану вартість, у розмірі суми коштів, що перевищує суму задекларованих до сплати до бюджету податкових зобов'язань та суми податкового боргу з податку.

При цьому, п. $200^{1} .6$ ст. $200^{1}$ Податкового кодексу [1] визначено яким саме чином, з урахуванням показників податкової звітності 3 ПДВ та електронного рахунку, відбуваються розрахунки з бюджетом (перерахування до бюджету) та/або повернення коштів на поточний рахунок платника.

На перший погляд все дуже просто, є електронній рахунок в СЕА ПДВ, який містить інформацію щодо суми ПДВ (реєстраційний ліміт), на яку платник податку може зареєструвати податкові накладні. За необхідності збільшення реєстраційної суми (ії недостатність 3 урахуванням отриманих податкових накладних) передбачена можливість його поповнення, в тому числі можливість поповнення для зарахування коштів в рахунок сплати поточних грошових зобов'язань з ПДВ. Доречно звернути увагу, що у разі поповнення грошовими коштами електронного рахунку для збільшення реєстраційного ліміту, подальша реєстрація податкових накладних призводить до його зменшення, тобто кошти списуються на відповідні рахунки державного бюджету (не можуть бути повернуті платнику). У разі наявності надміру сплачених грошових зобов'язань також можна повернути ці кошти на поточний рахунок використовуючи все той же електронний рахунок та податкову звітність.

Водночас, $є$ проблемні питання як технічного так і правового характеру щодо роботи з електронними рахунками в СЕА ПДВ. Так, наприклад мають місце випадки коли:

1. Платник податку має надміру сплачені грошові зобов'язанння з ПДВ, які були перераховані до бюджету з поточного рахунку платника в установі банку. В такому випадку, з урахуванням норм чинного законодавства платник може скористатись своїм правом і подати заяву на повернення надміру сплачених грошових зобов’язань. На підставі отриманої заяви контролюючим органом формуються відповідні реєстри, які в подальшому передаються до Держказначейства. Після чого такі кошти будуть повернуті платнику податку виключно на електронний рахунок в СЕА ПДВ. Знов ж таки звертаємо увагу, що для кон- 
тролюючого органу не має значення яким чином вони були сплачені (перераховані) до бюджету 3 електронного рахунку чи 3 поточного рахунку платника податку. В подальшому, лише після надходження їх на електронний рахунок, платник може повернути такі кошти на свій поточний рахунок в установі банку подавши разом із податковою звітністю заяву (додаток 4), у якій зазначити суму податку, яка підлягає поверненню.

2. Контрагентом (Покупцем) за вже поставлений товар, або який буде поставлений в майбутньому, перераховані кошти. Однак, у зв'язку із допущеною технічною помилкою під час здійснення платежу, такі кошти перераховані (надійшли) на електронний рахунок в СЕА ПДВ платника податку (Постачальника). Звісно платник податку, на електронний рахунок якого надійшли такі кошти 3 урахуванням вимог чинного законодавства може повернути такі кошти на свій поточний рахунок в установі банку подавши разом із податковою звітністю відповідну заяву (додаток 4). А вже потім повернути їх контрагенту.

В чому полягає схожість проблемних питань технічного та правового характеру на перший погляд двох абсолютно різних ситуацій. Забігаючи на перед зазначимо, що друга ситуація є складнішою і ми розглянемо її більш детально.

По-перше: в обох випадках кошти які надійшли на електронний рахунок не збільшать реєстраційний ліміт. По-друге: у разі їх списання (перерахування) з електронного рахунку на поточний рахунок платника податку реєстраційний ліміт буде зменшено на суму, яка перераховується з електронного рахунку на поточний. В даному випадку маємо ситуацію, з огляду на технічні недоліки роботи СЕА ПДВ, які також неврегульовані з правової точки зору, за яких платник податку втрачає право на реєстраційний ліміт (у зв'язку із його необгрунтованим зменшенням (показник $\left.\sum_{\text {Попрах }}\right)$ ) $[1 ; 3]$.

У чому ж полягає юридична проблематика ситуації з помилковим зарахуванням коштів на електронний рахунок іншого платника податку. Контрагент (Покупець), який помилково сплатив (перерахував) кошти на електронний рахунок платника податку (Постачальника), повернути їх самостійно на власний поточний рахунок не зможе, оскільки гроші зараховані на рахунок іншого платника податку. Як зазначалось вище повернення коштів з електронного рахунку мож- 
ливо лише платником податку, якому належить (для якого відкритий) такий електронний рахунок. При цьому, списання коштів 3 електронного рахунку в СЕА ПДВ відбувається Держказначейством виключно на підставі реєстрів сформованих контролюючим органом. Крім того, чинними нормативними актами, якими регулюється робота СЕА ПДВ не передбачений відповідний механізм повернення коштів $з$ електронного рахунку одного платника на поточний рахунок іншого.

Також, одним із питань, яке стосується вже суто взаємовідносин між двома суб'єктами господарювання, чи можна вважати кошти, зараховані на електронний рахунок, фактичною оплатою за товар (проведенням розрахунків). На наш погляд можна не вважати, вони хоч i надійшли платнику податків, але все ж таки якими він не може вільно розпоряджатись, оскільки вони зараховані на електронний рахунок.

Стосовно платника податку, на електронний рахунок якого помилково зараховані кошти, то такі кошти можливо повернути на поточний рахунок подавши разом з податковою звітністю з ПДВ відповідну заяву (Додаток 4) [4]. При цьому, повернення коштів з електронного рахунку призведе до зменшення суми реєстраційного ліміту відразу на дату подання звітності, з урахуванням показника $\sum_{\text {Попрах }}$, відповідно до п. 21 Постанови № 569 [3].

Проблема полягає у тому, що на суму коштів, які надійшли на електронний рахунок в СЕА ПДВ не з поточного рахунку платника податків, реєстраційний ліміт не збільшується [5; 6]. Водночас, у разі якщо платник податку скористається своїм правом та поверне ці кошти 3 електронного рахунку на свій поточний рахунок реєстраційний ліміт на відповідну суму коштів зменшиться. Тобто в ситуації з помилковим зарахуванням коштів на електронний рахунок іншого платника податку, платник податку, на електронний рахунок якого надійшли кошти, у разі їх повернення втрачає реєстраційний ліміт. Виникає необхідність його поповнення (вилучення обігових коштів)

На наш погляд контролюючий орган не збільшуючи ліміт на суму коштів, яка надійшла на електронний рахунок, порушує платника податків. При цьому зменшення реєстраційного ліміту за умови повернення коштів з електронного рахунку передбачено Податковим кодексом [1] тільки тому, що при зарахуванні коштів на електронний рахунок збільшується показник $\sum_{\text {Попрах }}$ Таким чином, у разі якщо кошти надійшли на 
електронний рахунок платника податку не з поточного рахунку такого платника реєстраційний ліміт не збільшується, однак при спробі їх повернути платник втрачає (зменшується) реєстраційний ліміт.

В даному випадку порушується збалансованість відносин платник податків та бюджетна система, адже одне без одного не може відбуватись. На нашу думку, якщо кошти надійшли на електронний рахунок вони повинні збільшувати реєстраційний ліміт, та відповідно у разі їх списання 3 електронного рахунку (повернення) реєстраційний ліміт повинен зменшуватись. Або навпаки, якщо законодавець вважає, що кошти, які надходять на електронний рахунок (повернення переплати 3 державного бюджету та/або помилкове зарахування з непоточного рахунку платника податку) не повинні збільшувати реєстраційний ліміт, то в такому випадку за фактом їх подальшого повернення на поточний рахунок платника податку вони не повинні його зменшувати.

Відповідно контролюючий орган повинен бути послідовним у своїй позиції не тільки з точки зору нормативного закріплення відповідних норм, але й $з$ технічної. Оскільки на думку останнього кошти, які надійшли на електронний рахунок в СЕА ПДВ не з поточного рахунку платника податку, не можуть збільшувати реєстраційний ліміт, то при їх поверненні вони не повинні призводити до його зменшення. Більш того, на наш погляд, в даному випадку кошти перераховані не 3 поточного рахунку платника податку взагалі не повинні зараховуватись на електронний рахунок, а повинні або автоматично повертатися особі, яка ініціювала переказ, або обліковуватись на відповідних рахунках як помилково сплачені.

Аналогічна ситуація стосовно суми ПДВ, яка повертається з бюджету як надміру сплачена через електронний рахунок. Як з точки зору правового так і технічного закріплення (належне врегулювання), вона не повинна створювати незручностей для платника податку та призводити до порушення відповідно балансу. Доречним $є$ внесення змін як технічного, так і нормативного характеру щодо роботи СЕА ПДВ.

\section{4. Судова практика}

За наведеною вище ситуацією позиція судів теж не однозначна. На даний момент $з$ наведеного питання наявні два судових рішення та лише судів перших інстанцій (одне з яких позитивне для платника податку та набрало законної сили). 
Так, у справі № 580/4761/20 [7] Черкаський окружний адміністративний суд, за наслідками розгляду адміністративного позову, відмовив у задоволенні позовних вимог Позивачу (повернення коштів, помилково перерахованих на електронний рахунок іншого платника податку). Відмовляючи у задоволенні позову судом першої інстанції наведено наступні аргументи:

- положення п. $200^{1} .6$ ст. $200^{1}$ Податкового кодексу передбачають, що кошти, які зараховані на рахунок в СЕА ПДВ, повертаються на поточний рахунок саме такого платника податку. Повернення коштів іншому платнику податків нормою п. 2001.6 ст. 2001 Податкового кодексу не передбачено;

- правовий статус грошових коштів, які зараховані на електронний рахунок в СЕА ПДВ, прирівнюється до коштів, які помилково сплачені одним суб'єктом господарювання на користь іншого. Таким чином, до спірних правовідносин не можуть бути застосовані норми п. 2001․6 ст. $200^{1}$ Податкового кодексу, тому повернення зазначених коштів позивач повинен звертатись до свого контрагента.

Наведене рішення $\epsilon$ цілком зрозумілим. В даному випадку суд першої інстанції виходив із положень норм чинного законодавства щодо роботи електронних рахунків. Однак, на наш погляд судом не враховано певна технічна специфіка роботи електронних рахунків, про які скоріш за все не вказував позивач та які неврегульовані належним чином з правової точки зору. При цьому, помилкове зарахування коштів на електронний рахунок іншого платника податків (контрагента) суд прирівняв до помилкового зарахування на інший звичайний (поточний) рахунок контрагента. В свою чергу, на нашу думку, в даній справі позивачу необхідно було б трохи в інший спосіб доводити обгрунтованість своїх позовних вимог.

Стосовно другого рішення, то воно є позитивним для платника податку. Додатково зазначимо, що вказане рішення набрало законної сили, адже все ж таки хотілося б почути думку Верховного суду. У справі № 280/5304/20 [8] Запорізький окружний адміністративний суд погодився та задовольнив вимоги позивача, а також зобов'язав:

- Держказначейство повернути суму коштів, помилково перераховану на електронний рахунок; 
- ДПС України не зменшувати реєстраційний ліміт за фактом повернення коштів з електронного рахунку на поточний рахунок платника податків.

Повністю погоджуємось 3 рішенням суду та вважаємо, що судом в повному обсязі досліджено обставини справи та надано належну правову оцінку. Крім того, судом об'єктивно зазначено, що якщо на електронний рахунок в СЕА ПДВ платника податку можливо перераховувати кошти виключно з поточного рахунку такого платника, то відповідно і Держказначейство не мало підстав зараховувати кошти на електронний рахунок одного платника, які надійшли 3 поточного рахунку іншого платника податку.

Доречним буде звернути увагу на те, що логічним 3 правової точки зору у даному випадку буде саме для платника податку (власника електронного рахунка) після встановлення факту помилкового надходження коштів на електронний рахунок від інших суб'єктів господарювання:

- отримати необхідні підтверджуючі документи щодо помилковості зарахування коштів на електронний рахунок (листи від контрагентів та ін.);

- звернутись до Держказначейства та ДПС України 3 проханням здійснити повернення помилково зарахованих коштів та отримати відповідь (на даний час на жаль вона буде негативною);

- звернутись 3 адміністративним позовом до суду з відповідними вимогами до Держказначейства та органів ДПС України. За можливості залучити стороною по справі суб'єкта господарювання (контрагента), вимогою якого може бути визнання неправомірними дій Держказначейства щодо зарахування коштів на електронний рахунок іншого платника податків.

\section{5. Висновки}

За результатами здійсненого аналізу:

1. Особливістю існування нормативно-правового забезпечення адміністрування податку на додану вартість в Україні були і досі $є$ правові колізії окремих положень законодавчих документів, що призводять до суперечок між контролюючими органами та платниками податків. Крім того, зазначене призводить до порушення збалансованості відносин платник податків та бюджетна система. 
2. Необхідним є внесення змін до нормативно-правових актів, якими регламентоване правове регулювання роботи системи електронного адміністрування податку на додану вартість, а також внесення змін до програмного забезпечення, якими удосконалити алгоритм роботи СЕА ПДВ. Вказаними змінами передбачити врегулювання наступних питань:

- кошти, які надходять на електронний рахунок (незалежно від джерела їх надходження, в тому числі повернення з бюджету надміру сплачених грошових зобов'язань), повинні збільшувати реєстраційний ліміт, або не зменшувати його, у разі їх подальшого повернення на поточний рахунок платника податку;

- визначення (врегулювання правових прогалин) механізму повернення коштів, помилково перерахованих на електронний рахунок 3 непоточного рахунку платника податку, або коштів, які помилково надійшли на електронний рахунок платника податку від інших платників. За можливості усунути недоліки в алгоритмі роботи СЕА ПДВ та передбачити автоматичне блокування (зарахування на відповідні транзитні рахунки як нез'ясовані) та/або автоматичне повернення Держказначейством коштів, які перераховуються на електронний рахунок не $з$ поточного рахунку такого платника.

3. В реаліях сьогодення, 3 правової точки зору платнику податку (власнику електронного рахунка) після встановлення факту помилкового надходження коштів на електронний рахунок від інших суб’ єктів господарювання бажано:

- отримати необхідні підтверджуючі документи щодо помилковості зарахування коштів на електронний рахунок (листи від контрагентів та ін.);

- звернутись до Держказначейства та ДПС України з проханням здійснити повернення помилково зарахованих коштів та отримати відповідь (на даний час на жаль вона буде негативною);

- звернутись 3 адміністративним позовом до суду з відповідними вимогами до Держказначейства та органів ДПС України. За можливості залучити стороною по справі суб'єкта господарювання (контрагента), вимогою якого може бути визнання неправомірними дій Держказначейства щодо зарахування коштів на електронний рахунок іншого платника податків. 


\section{Список літератури:}

1. Податковий кодекс України : Закон України від 02.12.2010 p. № 2755-VI. URL: https://zakon.rada.gov.ua/laws/show/2755-17\#Техt (дата звернення: 28.02.2021).

2. Про затвердження порядку ведення Єдиного реєстру податкових накладних : Постанова Кабінету Міністрів України від 29.12.2010 р. № 1246. URL: https://zakon.rada.gov.ua/laws/show/1246-2010-\%D0\%BF\#Text (дата звернення: 28.02.2021).

3. Деякі питання електронного адміністрування податку на додану вартість : Постанова Кабінету Міністрів України від 16.10.2014 р. № 569. URL: https://zakon.rada.gov.ua/laws/show/569-2014-\%D0\%BF\#Text (дата звернення: 28.02.2021).

4. Про затвердження форм та Порядку заповнення і подання податкової звітності з податку на додану вартість : Наказ Міністерства фінансів України від 28.01.2016 p. № 21. URL: https://zakon.rada.gov.ua/laws/show/z0159-16\#Text (дата звернення: 28.02.2021).

5. Загальнодоступний інформаційно-довідковий ресурс. URL: http://zir.sfs.gov.ua/ main/bz/view/?src=ques (дата звернення: 28.02.2021).

6. Електронний ПДВ-рахунок можна поповнювати тільки 3 поточного рахунку. Лист ГУ ДФС у Київській області від 29.12 .2018 р. № 5496/ IПК/10-36-12-01. URL: https://cutt.ly/0nbGxce (дата звернення: 28.02.2021).

7. Рішення Черкаського окружного адміністративного суду від 11.02 .2021 р. по справі № 580/4761/20. URL: https://reyestr.court.gov.ua/Review/94838256 (дата звернення: 28.02.2021).

8. Рішення Запорізького окружного адміністративного суду від 05.10 .2020 p. по справі № 280/5304/20. URL: https://reyestr.court.gov.ua/Review/92241807 (дата звернення: 28.02.2021).

\section{References.}

1. Podatkovyi kodeks Ukrainy (Verkhovna Rada Ukrainy) [Tax Code of Ukraine (Verkhovna Rada of Ukraine)]: Law of Ukraine No. 2755-VI (2010, December 2). Retrieved from: http://zakon5.rada.gov.ua/laws/show/2755-17\#Text (accessed 28 February 2021). (in Ukrainian)

2. Pro zatverdzhennia poriadku vedennia Yedynoho reiestru podatkovykh nakladnykh [On approval of the order of keeping the Unified register of tax invoices]: Postanova Kabinetu Ministriv Ukrainy [Decree of the Cabinet of Ministers of Ukraine] No. 1246 (2010, December 29). Retrieved from: https://zakon.rada.gov.ua/ laws/show/1246-2010-\%D0\%BF\#Text (accessed 28 February 2021). (in Ukrainian)

3. Dejaki pytannja elektronnogho administruvannja podatku na dodanu vartistj [Some issues of electronic administration of value added tax]: Postanova Kabinetu Ministriv Ukrainy [Decree of the Cabinet of Ministers of Ukraine] No. 569 (2014, October 16). Retrieved from: https://zakon.rada.gov.ua/laws/ show/569-2014-\%D0\%BF\#Text (accessed 28 February 2021). (in Ukrainian)

4. Pro zatverdzhennja form ta Porjadku zapovnennja i podannja podatkovoji zvitnosti z podatku na dodanu vartistj [On approval of the forms and the Order of 
filling and filing value added tax reports]: Nakaz Ministerstva finansiv Ukrajiny [Order of the Ministry of Finance of Ukraine] No. 21 (2016, January 28). Retrieved from: https://zakon.rada.gov.ua/laws/show/z0159-16\#Text (accessed 28 February 2021). (in Ukrainian)

5. Zaghaljnodostupnyj informacijno-dovidkovyj resurs [Open information and reference resource]. Retrieved from: http://zir.sfs.gov.ua/main/bz/view/?src=ques (accessed 28 February 2021). (in Ukrainian)

6. Elektronnyj PDV-rakhunok mozhna popovnjuvaty tiljky z potochnogho rakhunku. Lyst GhU DFS u Kyjivsjkij oblasti vid 29.12.2018 r. No. 5496/ IPK/10-36-12-01 [Electronic VAT-account can be topped up from current account. Letter of SFS in Kyiv oblast No. 5496/IПК/10-36-12-01 (2018, December 29)]. Retrieved from: https://cutt.ly/0nbGxce (accessed 28 February 2021). (in Ukrainian)

7. Rishennja Cherkasjkogho okruzhnogho administratyvnogho sudu vid 11.02.2021 r. po spravi No. 580/4761/20 [Resolution of Cherkassy district court on case No. 580/4761/20 (2021, February 11)]. Retrieved from: https://reyestr.court.gov.ua/ Review/94838256 (accessed 28 February 2021). (in Ukrainian)

8. Rishennja Zaporizjkogho okruzhnogho administratyvnogho sudu vid 05.10.2020 r. po spravi No. 280/5304/20 [Resolution of Zaporizhzhia district court on case No. 280/5304/20 (2020, October 5)]. Retrieved from: https://reyestr.court.gov.ua/ Review/92241807 (accessed 28 February 2021). (in Ukrainian) 